\title{
Metal Complexes of Macrocyclic Schiff-Base Ligand: Preparation, Characterisation, and Biological Activity
}

\author{
Riyadh M. Ahmed, Enaam I. Yousif, Hasan A. Hasan, and Mohamad J. Al-Jeboori \\ Department of Chemistry, College of Education, Ibn Al-Haitham, University of Baghdad, P.O. Box 4150, Adhamiyah, Baghdad, Iraq \\ Correspondence should be addressed to Mohamad J. Al-Jeboori; mohamadaljeboori@yahoo.com
}

Received 29 April 2013; Accepted 5 June 2013

Academic Editors: A. I. Matesanz and A. Souldozi

Copyright ( 2013 Riyadh M. Ahmed et al. This is an open access article distributed under the Creative Commons Attribution License, which permits unrestricted use, distribution, and reproduction in any medium, provided the original work is properly cited.

\begin{abstract}
A new macrocyclic multidentate Schiff-base ligand $\mathrm{Na}_{4} \mathrm{~L}$ consisting of two submacrocyclic units (10,21-bis-iminomethyl-3,6,14,17tricyclo[17.3.1.1 $\left.1^{8,12}\right]$ tetracosa-1(23),2,6,8,10,12(24),13,17,19,21,-decaene-23,24-disodium) and its tetranuclear metal complexes with $\mathrm{Mn}(\mathrm{II}), \mathrm{Co}(\mathrm{II}), \mathrm{Ni}(\mathrm{II}), \mathrm{Cu}(\mathrm{II})$, and $\mathrm{Zn}(\mathrm{II})$ are reported. $\mathrm{Na}_{4} \mathrm{~L}$ was prepared via a template approach, which is based on the condensation reaction of sodium 2,4,6-triformyl phenolate with ethylenediamine in mole ratios of $2: 3$. The tetranuclear macrocyclic-based complexes were prepared from the reaction of the corresponding metal chloride with the ligand. The mode of bonding and overall geometry of the compounds were determined through physicochemical and spectroscopic methods. These studies revealed tetrahedral geometries about $\mathrm{Mn}, \mathrm{Co}$, and $\mathrm{Zn}$ atoms. However, square planar geometries have been suggested for $\mathrm{Ni}^{\mathrm{II}}$ and $\mathrm{Cu}^{\mathrm{II}}$ complexes. Biological activity of the ligand and its metal complexes against Gram positive bacterial strain Staphylococcus aureus and Gram negative bacteria Escherichia coli revealed that the metal complexes become more potentially resistive to the microbial activities as compared to the free ligand. However, these metal complexes do not exhibit any effects on the activity of Pseudomonas aeruginosa bacteria. There is therefore no inhibition zone.
\end{abstract}

\section{Introduction}

Macrocyclic species based on transition metal compounds and multidentate ligands is an interesting field in chemistry and has been the subject of extensive research due to their potential applications in building block macrocyclic-based chemistry [1, 2] and environmental chemistry [3] and biomedical [4]. The chemistry of Schiff-base is an important field in coordination chemistry [5]. This is due to their ability to react with a range of metal ions forming stable complexes which have applications in different fields [6, 7]. One interesting application in the field of coordination chemistry has been to investigate the use of Schiff-base ligands to develop phenoxo-bridged binuclear complexes with homometallic and/or heterometallic centres. Complexes based on Schiffbase ligands play important roles in biomedical $[8,9]$, biomimetic, and catalytic systems $[10,11]$ and in supporting liquid crystalline phases [12]. A number of Schiff-base complexes have been used as oxygen carriers to mimic complicated biological systems [7, 11]. Furthermore, metal complexes of chromium, manganese, nickel, copper, zinc, and ruthenium with a wide variety of Schiff-bases are active oxidants for stoichiometric conversion and have been used as catalysts for carbonylation, hydrogenation, hydroformylation, and epoxidation reactions [13, 14]. Recently, we reported the formation of polymeric chain assemblies of some phenoxo-bridged binuclear transition metal complexes with multidentate Schiff-base ligand, namely, sodium(E)6,60-((1E,10E)-(ethane-1,2-diylbis(azan-1-yl-1-ylidene) bis(methan-1-yl-ylidene) bis-(4-methyl-2((E)(pyridine-2-ylmethylimino)methyl)phenolate) $\mathrm{H}_{2} \mathrm{~L}$. As part of our group to explore the use of multidentate Schiff-base ligands for the building blocks of macrocyclic compounds, we describe here the formation of macrocyclic species of some phenoxo-bridged tetranuclear transition metal ions with the new macrocyclic Schiff-base. The ligand was derived via a template approach in which ethylenediamine fragments facilitated the linkage of the two units (10,21-bis-iminomethyl-3,6,14,17-tricyclo[17.3.1.1 ${ }^{8,12}$ ] tetracosa-1(23),2,6,8,10, 12(24),13,17,19,21,-decaene-23,24-disodium). 


\section{Experimental}

2.1. Materials and Methods. All reagents were commercially available and used without further purification. Solvents were distilled from appropriate drying agents immediately prior to use.

2.2. Physical Measurements. Melting points were obtained on a Buchi SMP-20 capillary melting point apparatus and are uncorrected. IR spectra were recorded as $\mathrm{KBr}$ discs using a Shimadzu 8400 FTIR spectrophotometer in the range 4000$400 \mathrm{~cm}^{-1}$. Electronic spectra of the prepared compounds were measured in the region $250-900 \mathrm{~nm}$ for $10^{-3} \mathrm{M}$ solutions in $\mathrm{DMF}$ at $25^{\circ} \mathrm{C}$ using a Shimadzu 160 spectrophotometer. ${ }^{1} \mathrm{H}$ - and ${ }^{13} \mathrm{C}-\mathrm{NMR}$ spectra were acquired in DMSO$\mathrm{d}_{6}$ solution using a Brucker AMX400 MHz spectrometer with tetramethylsilane (TMS) as an internal standard. Mass spectra obtained by positive fast atom bombardment (FAB) were recorded on a VG autospec micromass spectrometer. Elemental analyses $(\mathrm{C}, \mathrm{H}$, and $\mathrm{N}$ ) were carried out on a Heraeus instrument (Vario EL). Metals were determined using a Shimadzu (A.A) $680 \mathrm{G}$ atomic absorption spectrophotometer. Chloride was determined using potentiometer titration method on a (686-Titro processor-665Dosimat-Metrohm Swiss). Conductivity measurements were made with DMSO solutions using a PW 9526 digital conductivity meter, and room temperature magnetic moments were measured with a magnetic susceptibility balance (Johnson Matthey Catalytic System Division).

\section{Synthesis}

3.1. Preparation of the Precursor Sodium (2,4,6-Triformyl Phenolate) (STFP). To a solution of $\mathrm{p}$-hydroxybenzaldehyde (12.2 g, $10 \mathrm{mmol})$, hexamethylenetetramine $(28.2 \mathrm{~g}, 20 \mathrm{mmol})$ in glacial acetic acid $(50 \mathrm{~mL})$, paraformaldehyde $(30 \mathrm{~g}$, $100 \mathrm{mmol}$ ) was added. The mixture was allowed to stir continuously until the deep orange viscous solution was obtained, and then heated up to $90^{\circ} \mathrm{C}$ for two hours. The solution was allowed to cool to room temperature, and then concentrated $\mathrm{H}_{2} \mathrm{SO}_{4}(10 \mathrm{~mL})$ was carefully added. The resulting solution was refluxed for $30 \mathrm{~min}$, and on treatment with distilled water $(400 \mathrm{~mL})$, a light orange precipitate was formed, which was stored overnight at $4^{\circ} \mathrm{C}$. The orange product was isolated by filtration and washed in small amount of cold methanol to obtain 2,4,6-triformyl phenol (tfp) [15]. The yielded product (TFP) $(59 \%, 10.5 \mathrm{~g})$ was mixed with equimolar amounts of $\mathrm{NaOH}(2.35 \mathrm{~g}, 5.8 \mathrm{mmol})$ in ethanol $(25 \mathrm{~mL})$. The mixture was allowed to stir for $30 \mathrm{~min}$ to give the sodium salt product (STFP) as a red-orange powder [16]. Yield: 65\%, 7.66 g; m.p. $150^{\circ} \mathrm{C}$. IR data $\left(\mathrm{cm}^{-1}\right): 2995(\mathrm{C}-\mathrm{H})$ arom, 2924 and $2791(\mathrm{C}-$ $\mathrm{H})$ aldehydic, $1683(\mathrm{C}=\mathrm{O})$, and $1240(\mathrm{C}-\mathrm{O})$.

3.2. Preparation of $\mathrm{Na}_{4} \mathrm{~L}$. A solution of sodium 2,4,6triformyl phenolate (STFP) $(0.5 \mathrm{~g}, 2.4 \mathrm{mmol})$ in methanol $(15 \mathrm{~mL})$ was added slowly with stirring to a mixture of ethylenediamine $(0.22 \mathrm{~g}, 3.6 \mathrm{mmol})$ dissolved in methanol $(15 \mathrm{~mL})$, and then $2-4$ drops of glacial acetic acid were added to the reaction mixture. The mixture was allowed to reflux with stirring. After $4 \mathrm{~h}$, the reaction was cooled to room temperature and then allowed to slowly evaporate to give a pale yellow viscous residue which was stirred for $30 \mathrm{~min}$ with a hot mixture of DMF/methanol 3:1 (15 mL). Solvent containing the required ligand was transferred to a vessel by decantation, and then solvent was removed under reduced pressure and residue was kept under vacuum for drying for $24 \mathrm{~h}$. Yield: $0.77 \mathrm{~g}, 33 \%$, m.p. $=178^{\circ} \mathrm{C}$. IR data $\left(\mathrm{cm}^{-1}\right)$ : $3008 v(\mathrm{C}-\mathrm{H})$ arom, $2723 \nu(\mathrm{C}-\mathrm{H})$ iminic, 1632 and $1622 \nu(\mathrm{C}=\mathrm{N}), 1350 \nu$ (phenoxide). The ${ }^{1} \mathrm{H}-\mathrm{NMR}$ spectrum of the ligand in DMSO- $\mathrm{d}_{6}$ showed peaks at $\delta_{\mathrm{H}}$ $\left(400 \mathrm{MHz}, \mathrm{DMSO}_{6}\right): 8.5(8 \mathrm{H}, \mathrm{s}, \mathrm{N}=\mathrm{C}-\mathrm{H}) ; 8.3(4 \mathrm{H}, \mathrm{s}$, $\mathrm{N}=\mathrm{C}-\mathrm{H}) ; 7.5(8 \mathrm{H}, \mathrm{s}, \mathrm{Ar}-\mathrm{H}) ; 4.5\left(16 \mathrm{H}, \mathrm{m}, \mathrm{N}-\mathrm{CH}_{2}\right) ; 3.1$ $\left(8 \mathrm{H}, \mathrm{m}, \mathrm{N}-\mathrm{C}-\mathrm{H}_{2}\right)$ and at $\delta_{\mathrm{c}}\left(100.63 \mathrm{MHz}, \mathrm{DMSO}-\mathrm{d}_{6}\right)$ : $57.49\left(\mathrm{CH}_{2} \mathrm{~N}=\mathrm{C}\right) ; 59.73\left(\mathrm{CH}_{2} \mathrm{~N}=\mathrm{C}\right) ; 117.91$ (Ar); 119.13 (Ar); 121.7 (Ar); 123.4 (Ar); 143.1 (Ar); 160.08 (C-O); 162.23 $(\mathrm{C}=\mathrm{N})$ imine; $164.01(\mathrm{C}=\mathrm{N})$ imine. The positive (FAB) mass spectrum of $\mathrm{Na}_{4} \mathrm{~L}$ showed a peak at $\mathrm{m} / z$ 967.103 (10\%) corresponding to $(\mathrm{M}+\mathrm{Na})^{+}$and the following fragments; 854.56 (32\%) $\left[\mathrm{M}-\left(\mathrm{Na}_{2} \mathrm{O}+\mathrm{CH}_{2} \mathrm{CH}_{2}\right)\right]^{+}, \quad 788.90$ (26\%) $\left[\mathrm{M}-\left\{\left(\mathrm{Na}_{2} \mathrm{O}+\mathrm{CH}_{2} \mathrm{CH}_{2}\right)^{+}(\mathrm{NaCH}=\mathrm{NO})\right\}\right]^{+}, 728.14(32 \%)[\mathrm{M}-$ $\left.\left(\mathrm{Na}_{2} \mathrm{O}+\mathrm{CH}_{2} \mathrm{CH}_{2}\right)+(\mathrm{NaCH}=\mathrm{NO})+\left(\mathrm{NH}_{2} \mathrm{CH}_{2} \mathrm{CH}_{2} \mathrm{NH}_{2}\right)\right]^{+}$,

$533.21 \quad(100 \%) \quad\left[\mathrm{M}-\left(\mathrm{Na}_{2} \mathrm{O}+\mathrm{CH}_{2} \mathrm{CH}_{2}\right)+(\mathrm{NaCH}=\mathrm{NO})\right.$ $\left.+\left(\mathrm{NH}_{2} \mathrm{CH}_{2} \mathrm{CH}_{2} \mathrm{NH}_{2}\right)+\left(\mathrm{C}_{10} \mathrm{H}_{10} \mathrm{NH}-\mathrm{C}=\mathrm{NNa}\right)\right]^{+}, 480.68$ (29\%) $\left[\mathrm{M}-\left(\mathrm{Na}_{2} \mathrm{O}+\mathrm{CH}_{2} \mathrm{CH}_{2}\right)+(\mathrm{NaCH}=\mathrm{NO})+\left(\mathrm{NH}_{2} \mathrm{CH}_{2} \mathrm{CH}_{2} \mathrm{NH}_{2}\right)\right.$ $\left.+\left(\mathrm{C}_{10} \mathrm{H}_{10} \mathrm{NH}-\mathrm{C}=\mathrm{NNa}\right)+\left(\mathrm{NaCH}_{2} \mathrm{NH}_{2}\right)\right]^{+}$.

3.3. General Synthesis of Complexes. A solution of the Schiff-base ligand $(1 \mathrm{mmol})$ dissolved in a $3: 1$ mixture of $\mathrm{DMF} / \mathrm{MeOH}(25 \mathrm{~mL})$ was allowed to stir for $15 \mathrm{~min}$. A methanolic solution $(15 \mathrm{~mL})$ of the metal(II) salt $(4.1 \mathrm{mmol})$ was then added dropwise, (metal (II) salts are hydrated chloride; $\mathrm{MCl} 2 \cdot \mathrm{XH} 2 \mathrm{O}\left(\mathrm{M}=\mathrm{Mn}^{\mathrm{II}}, \mathrm{X}=4 ; \mathrm{Co}^{\mathrm{II}}, \mathrm{Ni}^{\mathrm{II}}\right.$ and $\mathrm{Cu}^{\mathrm{II}}$; $\mathrm{X}=6,6$ and 2, respectively. Zinc chloride was no hydrated)). The reaction mixture was heated under $\mathrm{N}_{2}$ for $2 \mathrm{~h}$ on a water bath, resulting in the formation of a solid mass which was washed several times with hot methanol and then dried at room temperature. Elemental analysis data, colours and yields for the complexes are given in Table 1.

${ }^{1} \mathrm{H}$-NMR spectrum of $\left[\mathrm{Zn}_{4}{ }_{4}(\mathrm{~L})\right] \mathrm{Cl}_{4}$ in DMSO- $\mathrm{d}_{6}$ showed peaks at $\delta_{\mathrm{H}}\left(400 \mathrm{MHz}, \mathrm{DMSO}-\mathrm{d}_{6}\right): 3.8\left(8 \mathrm{H}, \mathrm{m}, \mathrm{N}-\mathrm{C}-\mathrm{H}_{2}\right), 5.2$ $\left(16 \mathrm{H}, \mathrm{m}, \mathrm{N}-\mathrm{C}-\mathrm{H}_{2}\right), 7.3(8 \mathrm{H}, \mathrm{d}, 9.8 \mathrm{~Hz}, \mathrm{Ar}-\mathrm{H}), 8.1(4 \mathrm{H}, \mathrm{br}$, $\mathrm{N}=\mathrm{C}-\mathrm{H})$, and $8.7(8 \mathrm{H}, \mathrm{br}, \mathrm{N}=\mathrm{C}-\mathrm{H})$.

3.4. Determination of Biological Activity. Bioactivities were investigated using agar-well diffusion method [17]. The wells were dug in the media with the help of a sterile metallic borer with centres at least $24 \mathrm{~mm}$. Recommended concentration $(100 \mu \mathrm{L})$ of the test sample $1 \mathrm{mg} / \mathrm{mL}$ in DMSO was introduced in the respective wells. The plates were incubated immediately at $37^{\circ} \mathrm{C}$ for 20 hours. Activity was determined by measuring the diameter of zones showing complete inhibition ( $\mathrm{mm}$ ). To examine the role of DMSO in the biological screening, separate studies were conducted with the solutions alone of DMSO, which showed no activity against any bacterial strains. All these complexes were found to be potentially active against these bacterial strains, except for the strain of Pseudomonas aeruginosa. 
TABLE 1: Colours, yields, elemental analyses, and molar conductance values.

\begin{tabular}{lccccccccc}
\hline \multirow{2}{*}{ Compound } & \multirow{2}{*}{ Colour } & \multirow{2}{*}{ Yield (\%) } & m.p. & \multicolumn{7}{c}{ Found (calcd.) (\%) } & $\mathrm{C}$ & $\mathrm{H}$ & $\mathrm{N}$ & $\mathrm{M}$ & $\mathrm{Cl}$ & $\Lambda_{M}\left(\mathrm{~cm}^{2} \Omega^{-1} \mathrm{~mol}^{-1}\right)$ \\
\hline $\mathrm{Na}_{4} \mathrm{~L}$ & Pale yellow & 47 & 178 & $60.4(61.6)$ & $4.52(4.9)$ & $17.7(18.4)$ & - & - & \\
{$\left[\mathrm{Mn}^{\mathrm{II}}(\mathrm{L})\right] \mathrm{Cl}_{4}$} & Brown & 44 & 285 & $46.6(47.4)$ & $3.4(3.7)$ & $13.6(13.8)$ & $17.6(18.1)$ & $10.7(11.7)$ & 294.01 \\
{$\left[\mathrm{Co}^{\mathrm{II}}(\mathrm{L})\right] \mathrm{Cl}_{4}$} & Red-brown & 50 & 320 & $46.2(46.9)$ & $3.4(3.6)$ & $13.4(13.7)$ & $18.1(19.2)$ & $10.9(11.5)$ & 295.58 \\
{$\left[\mathrm{Ni}_{4}^{\mathrm{II}}(\mathrm{L})\right] \mathrm{Cl}_{4}$} & Green & 46 & 305 & $46.36(46.9)$ & $3.33(3.6)$ & $13.39(13.7)$ & $18.14(19.1)$ & $10.88(11.5)$ & 292.71 \\
{$\left[\mathrm{Cu}^{\mathrm{II}}(\mathrm{L})\right] \mathrm{Cl}_{4}$} & Green & 42 & 270 & $45.9(46.2)$ & $3.3(3.6)$ & $13.2(13.5)$ & $19.8(20.4)$ & $10.9(10.3)$ & 291.08 \\
{$\left[\mathrm{Zn}_{4}{ }_{4}(\mathrm{~L})\right] \mathrm{Cl}_{4}$} & Yellow & 42 & 265 & $44.86(45.8)$ & $3.4(3.5)$ & $13.2(13.4)$ & $19.9(20.8)$ & $10.1(9.3)$ & 297.14 \\
\hline
\end{tabular}

\section{Results and Discussion}

4.1. Chemistry. A template approach was implemented to obtain the Schiff-base $\mathrm{Na}_{4} \mathrm{~L}$ in a reasonable yield (Scheme 1). Using $\mathrm{Na}^{+}$ion was found to be essential to form the ligand since otherwise only a polymeric mixture, partially soluble in hot DMF, was recovered via direct approach. The ligand was prepared from the reaction of sodium 2,4,6-triformyl phenolate (STFP) with ethylenediamine in mole ratios $2: 3$, respectively. The Schiff-base is soluble with stirring in DMF and DMSO but not in other common organic solvents. The ligand was characterised by elemental analysis (Table 1), IR (Table 2) and UV-Vis (Table 3) spectroscopy, and ${ }^{1} \mathrm{H}$ - and ${ }^{13} \mathrm{C}-\mathrm{NMR}$ spectroscopy. The IR spectrum of the free Schiffbase shows characteristic bands at 1632, 1622, 1350, and $1031 \mathrm{~cm}^{-1}$ due to the $v(\mathrm{C}=\mathrm{N}), v($ phenoxide), and $\nu(\mathrm{C}-\mathrm{O})$ functional groups, respectively. The UV-Vis spectrum of $\mathrm{Na}_{4} \mathrm{~L}$ exhibits an intense absorption peak at $295 \mathrm{~nm}$, assigned to $\pi \rightarrow \pi^{*}$. The peak at $322 \mathrm{~nm}$ assigned to $n \rightarrow \pi^{*}$ transition.

The bridged phenoxy tetranuclear complexes with $\mathrm{Mn}^{\mathrm{II}}$, $\mathrm{Co}^{\mathrm{II}}, \mathrm{Ni}^{\mathrm{II}}, \mathrm{Cu}^{\mathrm{II}}$ and $\mathrm{Zn}^{\mathrm{II}}$ were synthesised by heating $1 \mathrm{mmole}$ of the ligand with $4.1 \mathrm{mmole}$ of the metal chloride in a mixture of DMF/MeOH. Complexes of general formula $\left[\mathrm{M}^{\mathrm{II}}(\mathrm{L})\right] \mathrm{Cl}_{4}$ $\left(\left(\mathrm{M}=\mathrm{Mn}^{\mathrm{II}}, \mathrm{Co}^{\mathrm{II}}, \mathrm{Ni}^{\mathrm{II}}, \mathrm{Cu}^{\mathrm{II}}\right.\right.$, and $\left.\mathrm{Zn}^{\mathrm{II}}\right)$ were obtained, Scheme 1). The complexes are air-stable solids, soluble in hot DMSO and DMF but not in other common organic solvents. The coordination geometries of the complexes were deduced from their spectra. The analytical data (Table 1) agree well with the suggested formulae. Conductivity measurements of $\mathrm{Mn}^{\mathrm{II}}$, $\mathrm{Co}^{\mathrm{II}}, \mathrm{Ni}^{\mathrm{II}}, \mathrm{Cu}^{\mathrm{II}}$, and $\mathrm{Zn}^{\mathrm{II}}$ complexes in DMF lie in the 291.08$297.14 \mathrm{~cm}^{2} \Omega^{-1} \mathrm{~mol}^{-1}$ range, indicating their $1: 4$ electrolytic behaviour (Table 1) [18].

4.2. FTIR and NMR Spectra. The most important infrared bands for the complexes together with their assignments are listed in Table 2. The IR spectra of the complexes exhibited ligand bands with the appropriate shifts due to complex formation. The $v(\mathrm{C}=\mathrm{N})$ imine stretching band at $1632 \mathrm{~cm}^{-1}$ in the free Schiff-base is shifted to lower frequency and is observed at around $1589 \mathrm{~cm}^{-1}$ for the complexes. The bands are assigned to a $\nu(\mathrm{C}=\mathrm{N})$ stretch of reduced bond order. This can be attributed to delocalisation of metal electron density $\left(t_{2 g}\right)$ to the $\pi$-system of the ligand $[19,20]$, indicating coordination of nitrogen of the $\mathrm{C}=\mathrm{N}$ moieties to the metal atoms [21]. In addition, the IR spectra of the complexes display peaks around $1620 \mathrm{~cm}^{-1}$, which may be attributed to the $\nu(\mathrm{C}=\mathrm{N})$
TABLE 2: FTIR frequencies in $\left(\mathrm{cm}^{-1}\right)$ of the compounds.

\begin{tabular}{lcccc}
\hline Compound & $\nu(\mathrm{C}=\mathrm{N})_{\text {iminic }}$ & $\nu($ Phenoxide $)$ & $\nu(\mathrm{M}-\mathrm{N})$ & $\nu(\mathrm{M}-\mathrm{O})$ \\
\hline $\mathrm{Na}_{4} \mathrm{~L}$ & 1632,1622 & 1350 & - & - \\
{$\left[\mathrm{Mn}^{\mathrm{II}}{ }_{4}(\mathrm{~L})\right] \mathrm{Cl}_{4}$} & 1575,1618 & 1528 & 619 & 516 \\
{$\left[\mathrm{Co}^{\mathrm{II}}(\mathrm{L})\right] \mathrm{Cl}_{4}$} & 1579,1620 & 1518 & 663 & 584 \\
{$\left[\mathrm{Ni}_{4}{ }_{4}(\mathrm{~L})\right] \mathrm{Cl}_{4}$} & 1581,1620 & 1525 & 688 & 565 \\
{$\left[\mathrm{Cu}_{4}{ }_{4}(\mathrm{~L})\right] \mathrm{Cl}_{4}$} & 1577,1617 & 1550 & 663 & 554 \\
{$\left[\mathrm{Zn}_{4}^{\mathrm{II}}(\mathrm{L})\right] \mathrm{Cl}_{4}$} & 1583,1622 & 1540 & 632 & 555 \\
\hline
\end{tabular}

imine stretching of the uncoordinated moieties. Further, bands in the region of $1518-1550 \mathrm{~cm}^{-1}$ in all the complexes suggest phenoxide bridging with the metal atoms $[22,23]$. At lower frequency, the complexes exhibited bands around 619-688 and 516-584 $\mathrm{cm}^{-1}$, which could be assigned to $\nu(\mathrm{M}-$ $\mathrm{N})$ and $\nu(\mathrm{M}-\mathrm{O})$ vibration modes, respectively $[19,24]$. Due to the larger dipole moment change for $\mathrm{M}-\mathrm{O}$ compared to $\mathrm{M}-\mathrm{N}$, the $\nu(\mathrm{M}-\mathrm{O})$ usually appears at higher frequency than the $v(\mathrm{M}-\mathrm{N})$ band [25]. The electronic spectra and magnetic moment data of the complexes are summarised in Table 3.

The ${ }^{1} \mathrm{H}$-NMR spectrum in DMSO- $\mathrm{d}_{6}$ of the free Schiffbase shows peaks at 8.5 and $8.3 \mathrm{ppm}$ assigned to $-\mathrm{CH}=\mathrm{N}-$ (imine) protons, indicating that the azomethine protons are nonequivalent. In addition, the spectrum revealed two peaks around 4.5 and $3.7 \mathrm{ppm}$ assigned to the $\mathrm{CH}_{2} \mathrm{~N}$ fragment. The appearance of two chemical shifts may be because of the formation of two types of azomethine, (i) the one that is involved in the formation of the submacrocyclic component, and (ii) the one that facilitated the linkage between the two submacrocyclic parts. The ${ }^{13} \mathrm{C}$-NMR displays two peaks at ca. $59 \mathrm{ppm}$ and two signals at ca. $162 \mathrm{ppm}$, indicating that the $\mathrm{CH}_{2} \mathrm{~N}$ groups and the azomethine moieties are in a different environment. The NMR data is in accordance with the IR result in which two different peaks for $\mathrm{C}=\mathrm{N}$ group were observed. The peak at $7.4 \mathrm{ppm}$ is assigned to protons of aromatic ring. The ${ }^{1} \mathrm{H}-\mathrm{NMR}$ spectrum of $\left[\mathrm{Zn}^{\mathrm{II}}{ }_{4}(\mathrm{~L})\right] \mathrm{Cl}_{4}$ showed that the peaks of the azomethine protons are nonequivalent. Peaks observed around $8.7 \mathrm{ppm}$ are related to the coordinated azomethine which are shifted slightly downfield, compared with those observed for the free ligand. A peak recorded at $8.1 \mathrm{ppm}$ is attributed to the free azomethine groups (uncoordinated). The doublet at $7.3 \mathrm{ppm}$ is assigned to protons of aromatic rings. The appearance of these protons as a doublet is due to mutual coupling and/or a fluctuation behaviour generated by $\left(-\mathrm{CH}_{2} \mathrm{CH}_{2}-\right)$ moieties [15]. In general, the 


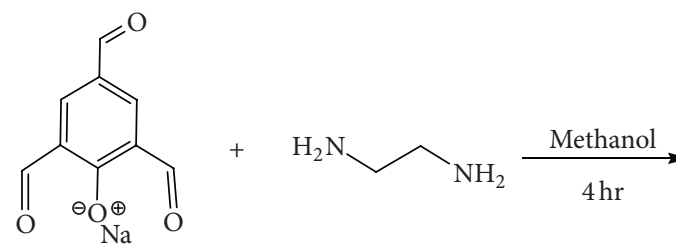

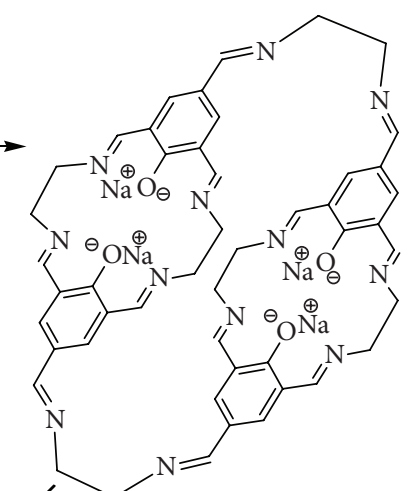

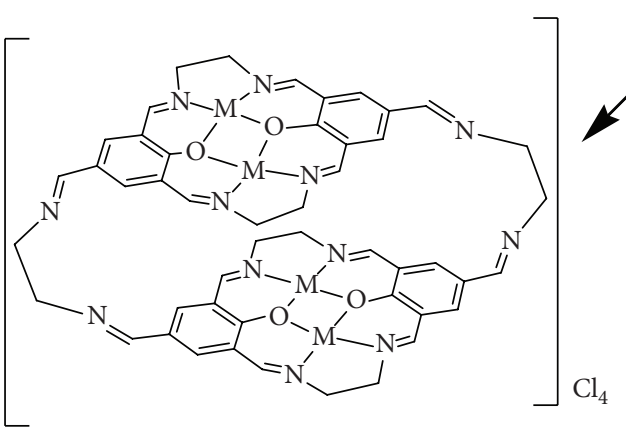

$\mathrm{M}=\mathrm{Mn}(\mathrm{II}), \mathrm{Co}(\mathrm{II}), \mathrm{Ni}(\mathrm{II}), \mathrm{Cu}(\mathrm{II})$, and $\mathrm{Zn}(\mathrm{II})$

Scheme 1: Synthesis scheme of the Schiff-base ligand $\mathrm{Na}_{2} \mathrm{~L}$ and it's complexes.

TABLE 3: Magnetic moment and UV-Vis spectral data in DMF solutions.

\begin{tabular}{|c|c|c|c|c|}
\hline Compound & $\mu_{\mathrm{eff}}(\mathrm{BM})$ & Band position $(\lambda \mathrm{nm})$ & Extinction coefficient $\varepsilon_{\max }\left(\mathrm{dm}^{3} \mathrm{~mol}^{-1} \mathrm{~cm}^{-1}\right)$ & Assignments \\
\hline \multirow{2}{*}{$\mathrm{Na}_{4} \mathrm{~L}$} & & 295 & 920 & $\pi \rightarrow \pi^{*}$ \\
\hline & & 322 & 850 & $\mathrm{CT}$ \\
\hline \multirow{3}{*}[\mathrm{Mn}_{4}^{\mathrm{II}}(\mathrm{L})]{$\mathrm{Cl}_{4}$} & \multirow{3}{*}{5.11} & 267 & 640 & $\pi \rightarrow \pi^{*}$ \\
\hline & & 318 & 530 & $\mathrm{CT}$ \\
\hline & & 423 & 360 & ${ }^{6} \mathrm{~A}_{1} \mathrm{~g} \rightarrow{ }^{4} \mathrm{~T}_{1} \mathrm{~g}$ \\
\hline \multirow{3}{*}[\mathrm{Co}_{4}^{\mathrm{II}}(\mathrm{L})]{$\mathrm{Cl}_{4}$} & \multirow{3}{*}{3.40} & 278 & 860 & $\pi \rightarrow \pi^{*}$ \\
\hline & & 343 & 432 & CT \\
\hline & & 461 & 123 & ${ }^{4} \mathrm{~T}_{1} \mathrm{~g}^{(\mathrm{F})} \rightarrow{ }^{4} \mathrm{~T}_{1} \mathrm{~g}^{(\mathrm{P})}$ \\
\hline \multirow{3}{*}[\mathrm{Ni}_{4}^{\mathrm{II}}(\mathrm{L})]{$\mathrm{Cl}_{4}$} & \multirow{3}{*}{0.02} & 271 & 758 & $\pi \rightarrow \pi^{*}$ \\
\hline & & 316 & 410 & CT \\
\hline & & 664 & 87 & ${ }^{1} \mathrm{~A}_{1} \mathrm{~g} \rightarrow{ }^{1} \mathrm{~A}_{2} \mathrm{~g}$ \\
\hline \multirow{3}{*}[\mathrm{Cu}_{4}{}_{4}(\mathrm{L})]{$\mathrm{Cl}_{4}$} & \multirow{3}{*}{1.51} & 283 & 323 & $\pi \rightarrow \pi^{*}$ \\
\hline & & 303 & 212 & $\mathrm{CT}$ \\
\hline & & 462 & 103 & ${ }^{2} \mathrm{~B}_{1} \mathrm{~g} \rightarrow{ }^{2} \mathrm{Eg}$ \\
\hline \multirow{2}{*}[\mathrm{Zn}^{\mathrm{II}}{}_{4}(\mathrm{L})]{$\mathrm{Cl}_{4}$} & \multirow{2}{*}{ Diamagnetic } & 291 & 574 & $\pi \rightarrow \pi^{*}$ \\
\hline & & 311 & 1235 & CT \\
\hline
\end{tabular}

spectrum showed broader peaks compared with that for the free ligand. This may point out that a fluctuation behaviour occurred in DMSO solution.

4.3. Mass Spectra. The mass spectrum of the ligand was consistent with the proposed structural formula (Section 3 ). The positive ion FAB mass spectrum for $\left[\mathrm{Cu}^{\mathrm{II}}{ }_{4}(\mathrm{~L})\right] \mathrm{Cl}_{4}$ showed several peaks corresponding to successive fragmentation of the molecule. The mass spectrum of $\mathrm{Cu}$ (II) complex does not display a peak may refer to molecular ion peak. The first peak observed at $m / z 1179$ represents the molecular ion peak of the complex losing $2 \mathrm{Cl}$ moieties. Three distinct 
TABLE 4: Biological activity for Schiff-base macrocyclic ligand and its complexes.

\begin{tabular}{|c|c|c|c|c|c|c|}
\hline \multirow{2}{*}{ Compounds } & \multicolumn{2}{|c|}{ Staphylococcus aureus (+) } & \multicolumn{2}{|c|}{ Escherichia coli (-) } & \multicolumn{2}{|c|}{ Pseudomonas aeruginosa (-) } \\
\hline & $5 \mathrm{mM}$ & $10 \mathrm{mM}$ & $5 \mathrm{mM}$ & $10 \mathrm{mM}$ & $5 \mathrm{mM}$ & $10 \mathrm{mM}$ \\
\hline Free ligand & - & + & - & + & - & - \\
\hline $\begin{array}{l}{\left[\mathrm{Mn}^{\mathrm{II}}{ }_{4}(\mathrm{~L})\right] \mathrm{Cl}_{4}} \\
{\left[\mathrm{Co}_{4}{ }_{4}(\mathrm{~L})\right] \mathrm{Cl}_{4}}\end{array}$ & ++ & +++ & + & ++ & - & - \\
\hline$\left[\mathrm{Ni}_{4}^{\mathrm{II}}(\mathrm{L})\right] \mathrm{Cl}_{4}$ & ++ & +++ & + & ++ & - & - \\
\hline$\left[\mathrm{Cu}_{4}^{\mathrm{II}}(\mathrm{L})\right] \mathrm{Cl}_{4}$ & ++ & +++ & + & ++ & - & - \\
\hline$\left[\mathrm{Zn}_{4}^{\mathrm{II}}(\mathrm{L})\right] \mathrm{Cl}_{4}$ & - & + & ++ & +++ & - & - \\
\hline
\end{tabular}

(-): No inhibition/inactive, (+): (3-5) $\mathrm{mm} /$ active, $(++):(6-8) \mathrm{mm} /$ more active, $(+++)$ : (9-14) $\mathrm{mm} /$ highly active.

peaks were observed in the mass spectrum at $m / z 1116$, 932, and 902 which can be assigned to the fragments [M$\{(2 \mathrm{Cl}+\mathrm{Cu}+\mathrm{H})\}]^{+}, \quad\left[\mathrm{M}-\left(4 \mathrm{Cl}+\mathrm{Cu}+\left(\mathrm{CH}_{2} \mathrm{CH}_{2}\right)_{3}+\mathrm{N}_{2}\right)\right]^{+}, \quad$ and $\left[\mathrm{M}-\left(4 \mathrm{Cl}+\mathrm{Cu}+\left(\mathrm{CH}_{2} \mathrm{CH}_{2}\right)_{3}+\mathrm{N}_{2}+\mathrm{O}_{2}\right)+\mathrm{H}\right]^{+}$, respectively. The $\mathrm{FAB}(+)$ mass spectrum for $\left[\mathrm{Co}_{4}^{\mathrm{II}}(\mathrm{L})\right] \mathrm{Cl}_{4}$ showed several peaks corresponding to successive fragmentation of the molecule. However, the spectrum failed to show a peak that refers to molecular ion peak. The first peak observed at $m / z 1106$ represents the molecular ion peak of the complex losing $\left(2 \mathrm{Cl}+\mathrm{CH}_{2} \mathrm{CH}_{2} \mathrm{CN}\right)$ fragment. Four distinct peaks were observed in the mass spectrum at $m / z 897,751,518$, and 328, can be assigned to the fragments $\left[\mathrm{M}-\left\{\left(2 \mathrm{Cl}+\mathrm{CH}_{2} \mathrm{CH}_{2} \mathrm{CN}\right)+\right.\right.$ $\left.\left(2 \mathrm{Cl}+\mathrm{Co}+\mathrm{CH}_{2} \mathrm{CH}_{2}+(\mathrm{CN})_{2}\right\}\right]^{+},\left[\mathrm{M}-\left\{\left(2 \mathrm{Cl}+\mathrm{CH}_{2} \mathrm{CH}_{2} \mathrm{CN}\right)+(2 \mathrm{Cl}\right.\right.$ $\left.\left.\left.+\mathrm{Co}+\mathrm{CH}_{2} \mathrm{CH}_{2}+(\mathrm{CN})_{2}+\left(\mathrm{CH}_{2} \mathrm{CH}_{2}\right)_{2}+\mathrm{Co}+\mathrm{O}_{2}\right)\right\}\right]^{+}, \quad[\mathrm{M}-\{(2 \mathrm{Cl}$ $\left.+\mathrm{CH}_{2} \mathrm{CH}_{2} \mathrm{CN}\right)+\left(2 \mathrm{Cl}+\mathrm{Co}+\mathrm{CH}_{2} \mathrm{CH}_{2}+(\mathrm{CN})_{2}+\left(\mathrm{CH}_{2} \mathrm{CH}_{2}\right)_{2}+\mathrm{Co}\right.$ $\left.\left.\left.+\mathrm{O}_{2}\right)+\left(\mathrm{C}_{12} \mathrm{H}_{16} \mathrm{~N}_{4} \mathrm{O}\right)\right\}\right]^{+}$, and $\left[\mathrm{M}-\left\{\left(2 \mathrm{Cl}+\mathrm{CH}_{2} \mathrm{CH}_{2} \mathrm{CN}\right)+(2 \mathrm{Cl}\right.\right.$ $\left.+\mathrm{Co}+\mathrm{CH}_{2} \mathrm{CH}_{2}+(\mathrm{CN})_{2}+\left(\mathrm{CH}_{2} \mathrm{CH}_{2}\right)_{2}+\mathrm{Co}+\mathrm{O}_{2}\right)+\left(\mathrm{C}_{12} \mathrm{H}_{16} \mathrm{~N}_{4} \mathrm{O}\right)$ $\left.\left.\left.+(\mathrm{CHNH})_{2}+\mathrm{CH}_{2} \mathrm{CH}_{2}+2 \mathrm{Co}\right)\right\}\right]^{+}$, respectively. The FAB (+) mass spectrum for $\left[\mathrm{Ni}_{4}{ }_{4}(\mathrm{~L})\right] \mathrm{Cl}_{4}$ showed several peaks corresponding to successive fragmentations of the molecule. However, no peak related to molecular ion peak was detected in the spectrum. The first peak observed at $m / z 1106$ represents the molecular ion peak of the complex losing $(2 \mathrm{Cl}$ $\left.+\mathrm{CH}_{2} \mathrm{CHCN}\right)^{+}$fragment. Five distinct peaks were observed in the mass spectrum at $m / z 1031,666,638,610$, and 500 , which can be assigned to the fragments $[\mathrm{M}-\{(2 \mathrm{Cl}$ $\left.\left.\left.+\mathrm{CHCH}_{2} \mathrm{CN}\right)+(\mathrm{NiO})\right\}\right]^{+}, \quad\left[\mathrm{M}-\left\{\left(2 \mathrm{Cl}+\mathrm{CHCH}_{2} \mathrm{CN}\right)+(\mathrm{NiO})\right.\right.$ $\left.\left.+\quad\left(\mathrm{C}_{14} \mathrm{H}_{13} \mathrm{~N}_{4} \mathrm{Ni}\right)\right\}\right]^{+}, \quad\left[\mathrm{M}-\left\{\left(2 \mathrm{Cl}+\mathrm{CHCH}_{2} \mathrm{CN}\right)+(\mathrm{NiO})+\right.\right.$ $\left.\left.\left(\mathrm{C}_{14} \mathrm{H}_{13} \mathrm{~N}_{4} \mathrm{Ni}\right)+\left(\mathrm{CH}_{2} \mathrm{CH}_{2}\right)\right\}\right]^{+},\left[\mathrm{M}-\left\{\left(2 \mathrm{Cl}+\mathrm{CHCH}_{2} \mathrm{CN}\right)+(\mathrm{NiO})\right.\right.$ $\left.\left.+\left(\mathrm{C}_{14} \mathrm{H}_{13} \mathrm{~N}_{4} \mathrm{Ni}\right)+\left(\mathrm{CH}_{2} \mathrm{CH}_{2}\right)+\left(\mathrm{CH}_{2} \mathrm{CH}_{2}\right)\right\}\right]^{+}$, and $[\mathrm{M}-\{(2 \mathrm{Cl}$ $\left.+\mathrm{CHCH}_{2} \mathrm{CN}\right)+(\mathrm{NiO})+\left(\mathrm{C}_{14} \mathrm{H}_{13} \mathrm{~N}_{4} \mathrm{Ni}\right)+\left(\mathrm{CH}_{2} \mathrm{CH}_{2}\right)$

$\left.\left.+\left(\mathrm{C}_{6} \mathrm{H}_{7} \mathrm{NO}\right)\right\}\right]^{+}$, respectively.

\subsection{Electronic Spectra and Magnetic Moment Measurements.} The electronic spectra of the complexes with the ligand exhibited various extents of hypsochromic shift of the bands related to the intraligand $\pi \rightarrow \pi^{*}$ transition. The electronic spectrum of the tetranuclear-Mn(II) Schiff-base complex showed additional peaks at 318 and $423 \mathrm{~nm}$ assigned to the charge transfer (CT) and $\mathrm{d}-\mathrm{d}$ transitions, respectively, in a distorted tetrahedral geometry $[26,27]$. The observed magnetic moment for the $\mathrm{Mn}$ (II) complex 5.1 B.M is typical for tetrahedral geometry [19]. The electronic spectrum of the $\mathrm{Co}(\mathrm{II})$ complex is consistent with tetrahedral assignment $[26,28]$. The spectrum of the Co(II) complex exhibited band characteristic of tetrahedral Co(II) complexes [26-29]. The magnetic moment was consistent with the tetrahedral environment around $\mathrm{Co}(\mathrm{II})$. The observed bands for the $\mathrm{Ni}$ (II) complex and its diamagnetic behaviour agrees well with the proposed square planar geometry $[26,30]$. The electronic spectrum of the $\mathrm{Cu}$ (II) complex displays a broad band assigned to ${ }^{2} \mathrm{~B}_{1} \mathrm{~g} \rightarrow{ }^{2} \mathrm{Eg}$ transition, corresponding to square planar geometry $[29,30]$. A magnetic moment of 1.51 B.M. is typical for four-coordinate copper complexes [31]. The spectrum of the $\mathrm{Zn}$ (II) complex exhibited bands assigned to ligand field $\pi \rightarrow \pi^{*}$ and $\mathrm{L} \rightarrow \mathrm{M}$ charge transfer $[26,32]$. The metal normally prefers tetrahedral geometry. The magnetic moment values for the tetranuclear macrocyclic complexes at RT are lower than the predicted values, indicating the presence of some antiferromagnetic interactions. This may occur from metal-metal interactions through the phenolic oxygen atoms and/or extensive electron delocalisation, which may be related to the formation of layer structures $[15,19,33]$.

\section{Biological Activity}

The free Schiff-base macrocyclic ligand and its metal complexes were screened against Staphylococcus aureus, Escherichia coli, and Pseudomonas aeruginosa to assess their potential as an antimicrobial agent by disc diffusion method. The measured zone of inhibition against the growth of various microorganisms is listed in Table 4. It is found that the metal complexes have higher antimicrobial activity against Gram negative species only compared with the free ligand. Hence complexation increases the antimicrobial activity. Such increased activity of the metal complexes can also be explained on the basis of chelation theory [33]. According to this, the chelation reduces the polarity of the metal atom mainly because of the partial sharing of its positive charge with donor group and possible $\pi$-electron delocalisation over the whole ring. This increases the lipophilic character of the metal chelate system which favours its permeation through lipid layer of the cell membranes.

\section{Conclusion}

In this paper, the synthesis and coordination chemistry of some macrocyclic-based tetranuclear metal complexes derived from the Schiff-base $\mathrm{Na}_{4} \mathrm{~L}$ are investigated. A template approach was used to prepare the ligand in a reasonable 
yield. The complexes were prepared by mixing at reflux 1 mmole of the Schiff base with 4 mmole of the appropriate metal chloride. Tetranuclear complexes of the general formulae $\left[\mathrm{M}_{4}(\mathrm{~L})\right] \mathrm{Cl}_{4}$ (where $\mathrm{M}=\mathrm{Mn}, \mathrm{Co}^{\mathrm{II}}, \mathrm{Ni}^{\mathrm{II}}, \mathrm{Cu}^{\mathrm{II}}$, and $\mathrm{Zn}^{\mathrm{II}}$ ) was obtained. Physicochemical analysis showed four cationic coordinate metal complexes were formed.

\section{References}

[1] J. M. Lehn, Supramolecular Chemistry Concepts and Perspectives, Wiley-VCH, Weinheim, Germany, 1st edition, 1995.

[2] B. Belghoul, I. Weiterlich, A. Maier, A. Toutianoush, A. Raman Rabindranath, and B. Tieke, "Supramolecular sequential assembly of polymer thin films based on dimeric, dendrimeric, and polymeric schiff-base ligands and metal ions," Langmuir, vol. 23, no. 9, pp. 5062-5069, 2007.

[3] B. K. Tripuramallu, R. Kishore, and S. K. Das, "Synthesis, structural characterization and properties of one-dimensional coordination polymers of cobalt(II)- and nickel(II)-phosphonate complexes with 2,2/-bipyridine as a secondary ligand component: observation of both cis and trans conformations of a diphosphonic acid," Polyhedron, vol. 29, no. 15, pp. 2985-2990, 2010.

[4] R. E. Mewis and S. J. Archibald, "Biomedical applications of macrocyclic ligand complexes," Coordination Chemistry Reviews, vol. 254, no. 15-16, pp. 1686-1712, 2010.

[5] K. B. Shiu, S. A. Liu, and G. H. Lee, "One-pot conditional selfassembly of multicopper metallacycles," Inorganic Chemistry, vol. 49, no. 21, pp. 9902-9908, 2010.

[6] O. Z. Yeşilel, H. Erer, G. Kaştaş, and I. B. Kani, "Hydrogen bonded networks and a self-assembled ID water cluster in nickel(II) and copper(II)-orotate complexes," Polyhedron, vol. 29, no. 13 , pp. $2600-2608,2010$.

[7] H. A. Habib, B. Gil-Hernández, K. Abu-Shandi, J. Sanchiz, and C. Janiak, "Iron, copper and zinc ammonium-1-hydroxyalkylidene-diphosphonates with zero-, one- and two-dimensional covalent metal-ligand structures extended into threedimensional supramolecular networks by charge-assisted hydrogen-bonding," Polyhedron, vol. 29, no. 12, pp. 2537-2545, 2010.

[8] M. J. Al-Jeboori and A. S. Al-Shihri, "An unusual coordination of potentially binucleating N2O Schiff base ligands with rhenium," Journal of Saudi Chemical Society, vol. 5, no. 3, p. 341, 2001.

[9] M. J. Al-Jeboori and A. A. Kashta, "Oxo-rhenium(V) complexes with tridentate Schiff base ligands," Mu'Tahlil-Buhuth Wadirasat, vol. 19, no. 1, p. 89, 2004.

[10] J. Costamagna, G. Ferraudi, B. Matsuhiro et al., "Complexes of macrocycles with pendant arms as models for biological molecules," Coordination Chemistry Reviews, vol. 196, no. 1, pp. 125164, 2000.

[11] P. K. Coughlin and S. J. Lippard, "Copper(II) chemistry in hexaaza binucleating macrocycles: hydroxide and acetate derivatives," Journal of the American Chemical Society, vol. 106, no. 8, pp. 2328-2336, 1984.

[12] A. Januszko, P. Kaszynski, and B. Grüner, "Liquid crystalline derivatives of bis(tricarbollide)Fe(II)," Inorganic Chemistry, vol. 46, no. 15, pp. 6078-6082, 2007.

[13] T. Katsuki, "Catalytic asymmetric oxidations using optically active (salen) manganese (III) complexes as catalysts," Coordination Chemistry Reviews, vol. 140, pp. 189-214, 1995.
[14] E. G. Samsel, K. Srinivasan, and J. K. Kochi, "Mechanism of the chromium-catalyzed epoxidation of olefins. Role of oxochromium(V) cations," Journal of the American Chemical Society, vol. 107, no. 25, pp. 7606-7617, 1985.

[15] M. J. Al-Jeboori, H. A. Hasan, and W. A. Jaafer Al-Sa'Idy, "Formation of polymeric chain assemblies of transition metal complexes with a multidentate Schiff-base," Transition Metal Chemistry, vol. 34, no. 6, pp. 593-598, 2009.

[16] S. Gou and D. E. Fenton, "A novel sodium template approach for preparing tetraimine macrocyles of 2,6-diformyl-4-methylphenol and diamino derivatives," Inorganica Chimica Acta, vol. 223, no. 1-2, pp. 169-172, 1994.

[17] A. U. Rahman, M. I. Choudhary, and W. J. Thomsen, Bioassay Techniques for Drug Development, Harwood Academic, Amsterdam, The Netherlands, 2001.

[18] W. J. Geary, "The use of conductivity measurements in organic solvents for the characterisation of coordination compounds," Coordination Chemistry Reviews, vol. 7, no. 1, pp. 81-122, 1971.

[19] M. J. Al-Jeboori, A. H. Al-Dujaili, and A. E. Al-Janabi, "Coordination of carbonyl oxygen in the complexes of polymeric N-crotonyl-2-hydroxyphenylazomethine," Transition Metal Chemistry, vol. 34, no. 1, pp. 109-113, 2009.

[20] S. E. Livingston, J. H. Mayfield, and D. S. Moorse, "Thio derivatives of $\beta$-diketones and their metal chelates. Magnetic moments of some ruthenium(III) chelates of fluorinated Monothio- $\beta$-diketones," Australian Journal of Chemistry, vol. 28, no. 11, pp. 2531-2533, 1975.

[21] A. Z. El-Sonbati, A. A. El-Bindary, and A. A. Al-Sarawy, "Stereochemistry of new nitrogen containing heterocyclic aldehyde. IX. Spectroscopic studies on novel mixed-ligand complexes of Rh(III)," Spectrochimica Acta A, vol. 58, no. 12, pp. 2771-2778, 2002.

[22] S. Sreedaran, K. S. Bharathi, A. K. Rahiman et al., "Synthesis, electrochemical, catalytic and antimicrobial activities of novel unsymmetrical macrocyclic dicompartmental binuclear nickel(II) complexes," Polyhedron, vol. 27, no. 7, pp. 1867-1874, 2008.

[23] J. A. M. Brandts, J. Boersma, A. L. Spek, and G. Van Koten, "Molybdenum(VI) bisimidoaryl phenoxide and alkoxide complexes: molecular structures of $\left[\mathrm{Mo}(\mathrm{NAr})_{2}\left(\mathrm{OCMe}_{2}-2\right.\right.$ py) $\left.\left(\mathrm{CH}_{2} \mathrm{SiMe}_{3}\right)\right]$ and $\left[\mathrm{Mo}(\mathrm{NAr})_{2} \mathrm{Me}(\mathrm{OMe})_{2}\right]$," European Journal of Inorganic Chemistry, no. 10, pp. 1727-1733, 1999.

[24] M. J. Al-Jeboori, A. S. A. Abdul Rahman, and S. Atia, "Synthesis and spectral studies on cobalt(II), nickel(II), copper(II), palladium(II), platinum(II, IV), zinc(II), cadmium(II) and mercury(II) complexes of (1,2-diaminoethane-N,N4-bis(2butylidine-3onedioxime," Ibn Al-Haitham Journal for Pure and Applied Science, vol. 18, no. 2, pp. 51-67, 2005.

[25] N. Ohkaku and K. Nakamoto, "Metal isotope effect on metalligand vibrations. VI. Metal complexes of 8-hydroxyquinoline," Inorganic Chemistry, vol. 10, no. 4, pp. 798-805, 1971.

[26] A. B. P. Lever, Inorganic Electronic Spectroscopy, Elsevier, New York, NY, USA, 2nd edition, 1984.

[27] B. N. Figgis, Introduction to Ligand Fields, Interscience Publishers, John Wiley and Sons, New York, NY, USA, 1967.

[28] O. S. M. Nasman, " $\mathrm{N}_{2} \mathrm{~S}_{2}$-donor macrocycles with some transition metal ions: synthesis and characterization," Phosphorus, Sulfur and Silicon and the Related Elements, vol. 183, no. 7, pp. 1541-1551, 2008.

[29] M. M. Aly, A. O. Baghlaf, and N. S. Ganji, "Linkage isomerism of the oximato group: the characterization of some mono- and 
binuclear square planar nickel(II) complexes of vicinal oximeimine ligands," Polyhedron, vol. 4, no. 7, pp. 1301-1309, 1985.

[30] E. Yousif, Y. Farina, K. Kasar, A. Graisa, and K. Ayid, "Complexes of 2-thioacetic acid benzothiazole with some metal ions," American Journal of Applied Sciences, vol. 6, no. 4, pp. 582-585, 2009.

[31] M. J. Al-Jeboori, H. H. Al-Tawel, and R. M. Ahmad, "New metal complexes of N2S2 tetradentate ligands: synthesis and spectral studies," Inorganica Chimica Acta, vol. 363, no. 6, pp. 1301-1305, 2010.

[32] B. J. Hathaway and D. E. Billing, “The electronic properties and stereochemistry of mono-nuclear complexes of the copper(II) ion," Coordination Chemistry Reviews, vol. 5, no. 2, pp. 143-207, 1970.

[33] R. V. Singh, R. Dwivedi, and S. C. Joshi, "Synthetic, magnetic, spectral, antimicrobial and antifertility studies of dioxomolybdenum(VI) unsymmetrical imine complexes having a $N \cap N$ donor system," Transition Metal Chemistry, vol. 29, no. 1, pp. 70$74,2004$. 

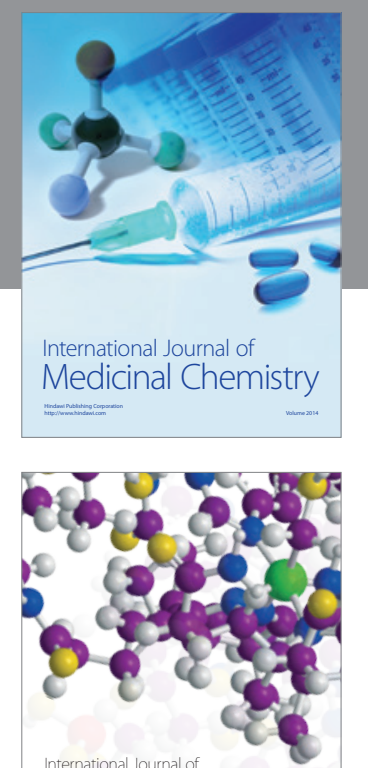

\section{Carbohydrate} Chemistry

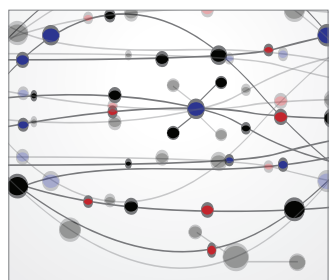

The Scientific World Journal
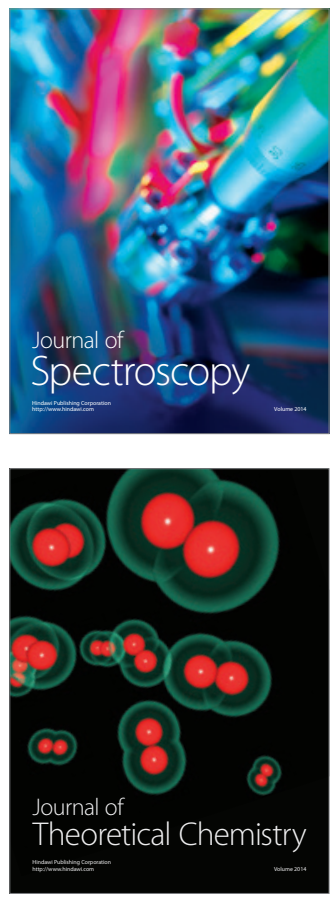
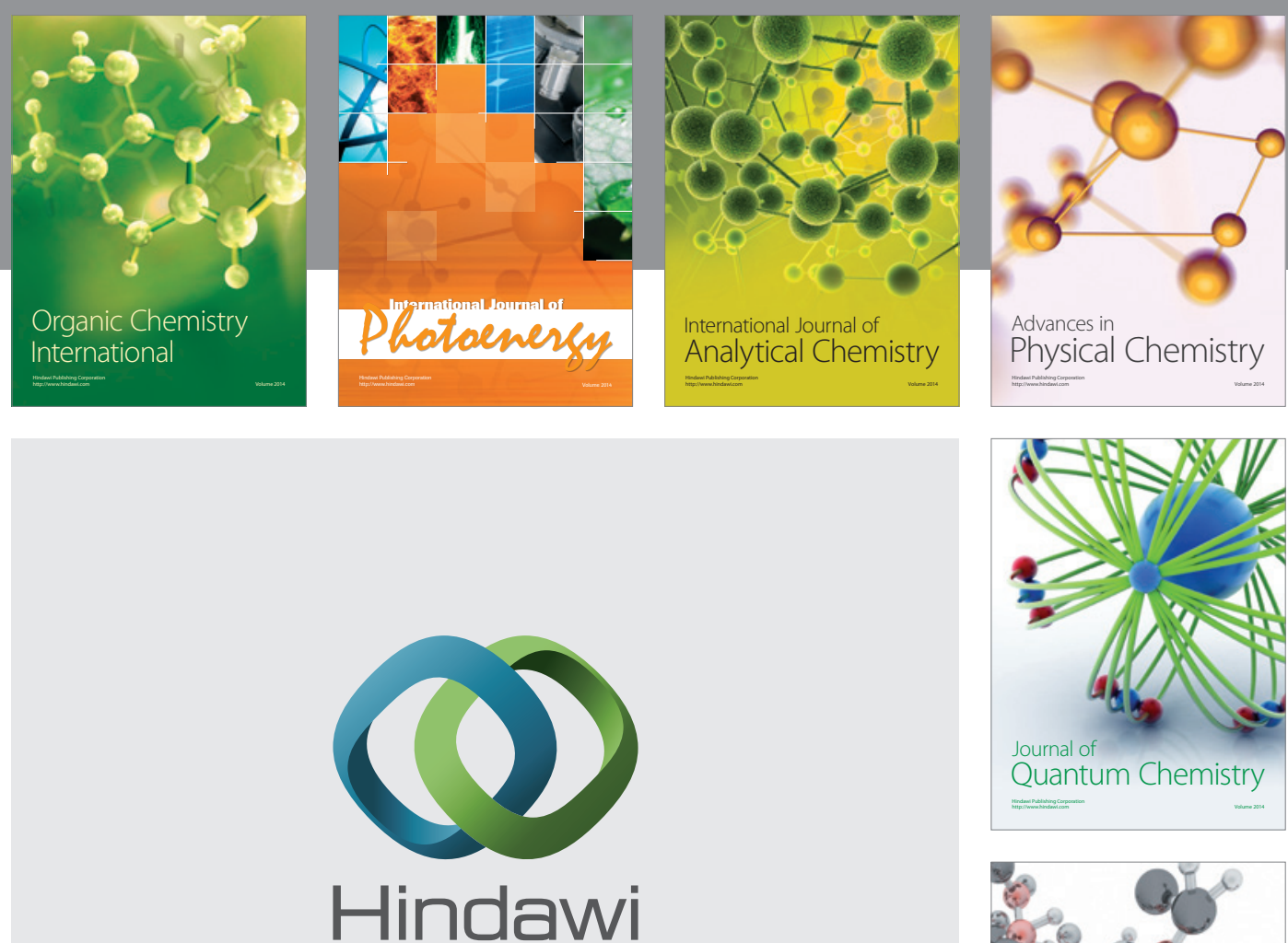

Submit your manuscripts at

http://www.hindawi.com

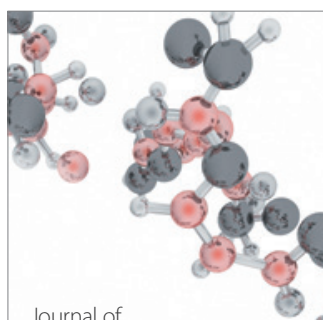

Analytical Methods

in Chemistry

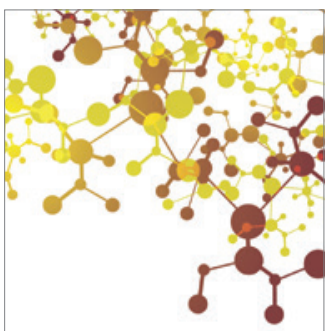

Journal of

Applied Chemistry

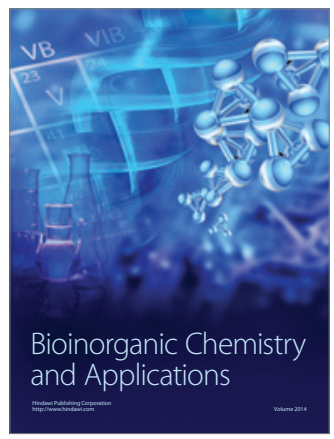

Inorganic Chemistry
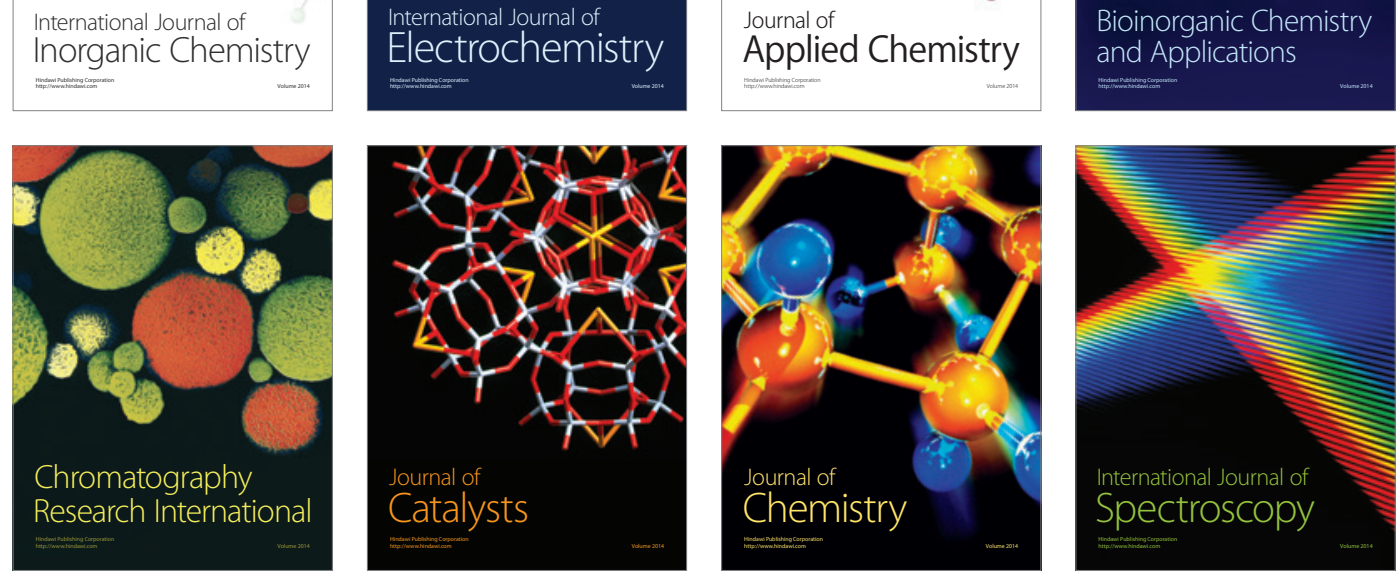